UDC 349.6

DOI https://doi.org/10.37687/2413-7189.2020.2.6

Kostytsky V.V.,

Doctor of Law (DrSc.), Professor,

Academician of the National Academy of Legal Sciences of Ukraine,

President of the International Environmental Academy,

Professor at the Department of Theory of Law and State

Taras Shevchenko National University of Kyiv

ORCID: 0000-0003-1692-9810

\title{
THE MODERN PROBLEMS OF THEORY ECOLOGICAL LAW
}

\section{СУЧАСНІ ПРОБЛЕМИ ТЕОРІЇ ЕКОЛОГІЧНОГО ПРАВА}

Features of the modern globalized world necessitate the reformulation of our ideas about law and the state and their role and place in the development of civil society [5]. In today's global civil society, people are willing to trust the elite. The choice of a model of interaction between society and the environment in a modern organized global civil society can no longer be the result of random decisions or the work of one or more states, it becomes a global task. The form of its solution may be the further improvement of national environmental law with the subsequent adoption of the Environmental Constitution of the Earth, which also requires clarification of many political and legal issues, especially theoretical and methodological. The problem of their formulation and solution, today, is superimposed on another very serious problem, which we call the problem of the crisis of modern jurisprudence, but rather even modern legal understanding.

Peculiarities of modern globalized world stipulate the necessity in reframing our ideas about law and state and their role and place in development of civil society. The development of legal system leads to severance of new legal branches and institutes. Therefore, we will logically begin our research of ecological law place and role in legal system from analysis of modern understanding law and legal system, law structure peculiarities and other theoretic and methodological problems. Finding out the question of the essence of a particular branch of law and its place in the system of law requires the study of the socio-legal bases of its origin, history of origin, principles and possible ways of development.

State legal system determines not only the form of government, political (legal) regime but also characterizes the features of its modern development, as the modern state cannot be isolated from the global world. Thus, law turns from limitation of law into phenomenon where system of person's limitations and his/her duties corresponds with state's duties and person's possibilities.

During the last decades in Ukraine the law was traditionally examined as a mirror of public relations reflected only attained level of development and deprived of creative force as a secondary (built-on) element of reality, an addition to economic relations which serves the tools of economy.

Key words: law, law, ecological law, sociological and legal problems of environmental protection.

Особливості сучасного глобалізованого світу зумовлюють необхідність переформулювання наших уявлень про право та державу та їх роль і місие у розвитку громадянського суспільства [5]. У сучасному глобальному громадянському суспільстві люди готові довірити еліті. Вибір моделі взаємодії суспільства і довкілля у сучасному організованому глобальному громадянському суспільстві уже не може бути результатом випадкових рімень або справою однієї чи кількох держав, стає загальнопланетарним завданням. Формою його вирімення може бути подальше удосконалення національного екологічного права з наступним ухваленням Екологічної Конституції Землі, шьо потребує також з'ясування багатьох політико-правових питань, насамперед теоретико-методологічних. Проблема їх постановки та вирішення накладається на іншу дуже серйозну проблему, яку називаємо проблемою кризи сучасного правознавства, а швидше навіть сучасного праворозуміння.

Розвиток правової системи призводить до припинення діяльності нових юридичних галузей та інститутів. Тому ми логічно розпочнемо дослідження місия та ролі екологічного права у правовій системі з аналізу сучасного розуміння права та правової системи, особливостей структури права та інших теоретичних і методологічних проблем. 3'ясування питання про сутність певної галузі права та ї̈ місце в системі права вимагає вивчення соціально-правових основ ї̈ походження, історії виникнення, принципів і можливих иляхів розвитку.

Державно-правова система визначає не тільки форму правління, політичний (правовий) режим, але $і$ характеризує особливості його сучасного розвитку, оскільки сучасна держава не може бути ізольована від глобального світу. Таким чином, право перетворюється з обмеження права на явище, де система обмежень людини та іï / ї̈ обов'язків відповідає обов'язкам держави та можливостям людини.

Протягом останніх десятиліть в Україні закон традиційно розглядався як дзеркало суспільних відносин, що відображає лише досягнутий рівень розвитку і позбавлене творчої сили як вторинного (вбудованого) елемента реальності, доповнення до економічних відносин, яке служить інструментом економіки.

Ключові слова: право, закон, екологічне право, сочіолого-правові проблеми охорони довкілля. 
Formulation of the problem. Law is a social phenomenon [1], an achievement of spiritual culture and art that is why law cannot be deprived of creative basis with the help of which new socio-economic relations develop. Ukrainian experience, the Constitution of Ukraine (1996), the project of which was created with the author's input as a model for development of the state, forming the legal system, civil society and a new free man, is the best argument in favour of such a statement.

Freedom and necessity are two real criteria, two real keys to understanding law as an integral phenomenon which combines public and private life of the society. Freedom per se is alive when like a bird it can have two wings, one of which is private life of a person, based on the right to one's own identity and private property, and the second is the right to participating in public life, obviously, foremost - the right to vote. And then the necessity is understood as a duty of an individual to take into account public and private interests while realizing one's own interests.

Contrary to legal system as a multitude of all legal phenomena the legal system includes fields of law and institutes of law. There arises a logical question whether it is possible to distinguish branches in the legal system which belongs to private law, and to designate fields of law which are public law. On the level of division of law into branches it is yet possible to talk about it: civil law undoubtedly makes the basis of private law. Natural law, as Ulpian said, also belongs to private law. There are rights and freedoms of a person in natural law which are inalienably proper to it as a biosocial creature and they cannot be given by the state, and only owing to their acknowledgement by the state must be recorded in the constitution as a public agreement of citizens inter se, the civil society and the state. Here the level of publicity of natural law corresponds to the level of publicity of civil law.

One of displays of integrity of law apart from its division into public and private and their unity is formation of a complex field of law - "ecological law" that combines in itself forms of public and private law, includes both norms of ecological law and norms of other fields of law.

Presenting main material. We can mention once again that a combination of norms of public and private law as demonstration of unity of law and its division into branches but, foremost, of its integrity, can be especially vividly seen in ecological law. Integrity of law is the law of its existence. In our opinion, economic and legal mechanism of environmental protection is one of displays of the integrity of law [2]. The task and optimal result of realization of economic and legal mechanism of protection of natural environment lies in achieving harmonious relations in the "society and nature" system which, for example, is possible to express through the concept of ecological legal order and ecological safety.
In any case the result of legal regulation of ecological relations must convey a certain state of public relations in the sphere of cooperation of society and nature, and in this case the quality of environment is favourable for a person and separate natural components, and the quality and the amount of natural resources cater for the economy of present and future generations of people [3].

Such efficiency of public relations is possible only under conditions of ecological stability which means the ability of an ecosystem to resist abiotic and biotic factors of the environment, including anthropogenic influences [4].

Law is practically the only, both effective and resultative, universal instrument of solution to these problems. Optimization of behavioural characteristics of participants of ecological relations on the basis of providing ecological vector in the system of their internal motivations are directed at balancing forms of cooperation of the society and nature.

The law of every state as a system which includes such structural units as branches of law is in permanent dynamics. Such peculiarities of law can be most vividly seen in ecological law which includes legal norms directed at environmental protection.

Thus, ecological law is a complex branch of law that regulates legal relations in the sphere of environmental protection, rational use of natural resources and providing ecological safety, i.e. relations related to protection and use of environment on the whole and natural resources of environment with the aim of providing permanent balanced development in interests of present and future generations of people.

In Ukraine the main characteristics of development of ecological law consists in expansion of its action, itemization of many legal requirements. A short process of its development in independent Ukraine underlines the fact that expansion of the sphere of ecological law is an objective process. The tendency of expansion of the sphere of ecological law in Ukraine is far from being exhausted even today. In particular, it is confirmed by the fact that the problem of substantial updating and perfection of ecological law acquires considerable importance. The point is that the intensity of formation of this branch of law has resulted in adoption of many hasty and imperfect legal norms which were often corrected in recent years. Weak financial and economic validity of many statements of ecological law has revealed itself. All this has required earlier and requires now permanent adjustment of a considerable number of existing normative materials, it often generates unsystematic and frequent changes in the mechanism of legal regulation of ecological relations, puts forward the need of codification of ecological law and adoption of the Ecological Code of Ukraine.

Ukrainian legal idea still has to find optimal principles of cooperation and differentiation of branches of law. Obviously, nowadays we should display patience and 
consideration, remembering that one or few legislative acts do not provide coordination and efficiency of public relations. A number of laws seem necessary, something similar to the "critical mass" in physics to make all the legal system "begin to work". Even within the limits of one branch of law it is difficult to obtain necessary effect without corresponding innovations in other branches of law. For instance, insufficient effectiveness of the Law of Ukraine "On Protection of Natural Environment" is largely stipulated by delay of alterations to the Code on Administrative Offences of Ukraine and absence of law on state control in the sphere of environmental protection.

Today we face the necessity of codification of ecological law and adoption of the Ecological Code of Ukraine which would take into account recent achievements not only of the law science but also of law-making and law-enforcement practice and new principles. The principles of environmental (ecological) legislation express the main objective laws of the mechanism of interaction between the individual, society and the natural environment of a person and determine the essence of environmental legislation. The principles of environmental legislation are an expression of public environmental interests, and operate within all sub-sectors and institutions of environmental legislation, are enshrined in the relevant provisions of the laws, act as the most concentrated supremacy of the principles of environmental law, and interact with the principles of environmental policy.

Principles of ecological law consist in fundamental ideas, basic principles, peculiarities, properties which are typical of all legal norms of ecological law, according to which regulation of ecological relations is carried out. From our point of view, the above-mentioned list of features has to be definitely complemented by such characteristics as requirements. Primarily, principles are nothing else but requirements in accordance with which certain legislative norms must be reflected in corresponding acts. Principles are the basis of construction and functioning of law, de facto they are obligatory in the part of inhibition for all the subjects of ecological relations without exception; their current state de jure determines the level of legal consciousness and culture of the society, in the part of the subject of research a level of its ecological behaviour. Principles of ecological law are characterized by the process of permanent development the dynamics of which is determined by transformation of tasks in the sphere of exploitation of natural resources, environmental protection and providing ecological safety in conditions of increased changeability of the environment, the system of ecological relations, largely predefined by the change of ecological requirements on national and international levels.

Principles of ecological law apart from its object and methods of legal regulation of ecological relations are criteria which allow to distinguish ecological law from other branches of law, to determine the nature of ecological law as a complex branch of law.
First of all, ecological law is based on the system of general (which determine the essence of law on the whole - principles of social justice and social freedom, equality (equal protection of the law), unity of legal rights and duties, lawfulness, inevitability, etc.) and special (branch-related - which concern and operate within the limits of one branch) principles. At the same time differences in approaches of a number of scientists take place in the part of systematization of basic principles of ecological law.

However, since the Law of Ukraine "On Protection of Natural Environment" was adopted many years have passed and today we can talk about a new system of principles of ecological law to which belong the following: priority of requirements of ecological safety, obligatoriness of inhibition of ecological standards, norms and limits of use of natural resources in the activity of public and local self-government bodies, and also in the process of realizing economic, administrative, humanitarian, social and other activity; duty of the state to guarantee the environment ecologically safe for life and health of people, to provide favourable ecological conditions of person's work and rest; realization of the principle "a polluter pays" in legislative activity and law enforcement of the state, in other words the introduction of paid access for industrial and economic activity which leads to environmental pollution and worsening the quality of natural resources, introduction of ecological taxes; ecological patriotism, realization of economic, political, humanitarian, social and other activity taking into account ecological interests of Ukraine, priority for society of life supporting (social, recreational, protective) functions of biosphere concerning direct (raw material) use of natural resources, use of national standards, if their requirements are more effective for achievement of tasks of environmental protection than international ones; principle of integration in realization of ecological measures of the state.

Application of any principle of environmental protection cannot lead to violation of the other principle or person's right to ecological safety and environmental protection.

Moral and ecological ethics are at the heart of making any environmentally sound decisions. The question of salvation of modern civilization lies in the field of environmental ethics, including through the adoption and implementation of the Earth's Ecological Constitution. The international legal environmental imperative (the moral imperative of good), as an ideal to which we would all strive together to preserve the Earth for our children and grandchildren, must obviously be the content of the Earth's Ecological Constitution, which should precede the harmonization of the constitutional consolidation of human rights. living in a favorable environment and other environmental rights as a condition and obligation of the state to ensure sustainable development and carry out an ecological function in accordance with the 
requirements of international and national environmental law. Such a need is also objectively attributed to the fact that it is now generally accepted to distinguish environmental law as a complex branch of law, which brings together a relatively independent set of rules of law governing certain spheres of social relations, united in separate branches, sub-branches and institutions of law.

Conclusions. The components of the development of law should be not only the further progress of environmental science, the enhancement of the ecological and legal culture, the improvement of the eco-legal education system, but, above all, the improvement of the legislation, taking into account the normative force of the law, its general binding nature. We now face the need to codify environmental legislation and adopt the Environmental Code of Ukraine, which would take into account the latest developments in both legal science and law-making and law enforcement.

The codification of environmental law must be carried out at the level of creation of new rules of law. After all, a legal rule - a specific rule of conduct, established or sanctioned and enforced by the state - is the least structural component of the environmental law system.

Therefore, environmental law is a complex area of law that regulates legal relations in the field of nature protection, rational use of natural resources and ensuring environmental safety, that is, relations related to environmental protection in general, protection and use of natural resources and protection of life and health. human beings due to the negative impact of human activity on the environment in order to ensure a balanced sustainable development for the benefit of present and future generations of people [5].

The human right to a clean environment in the constitutions of modern states is considered to be the legal basis for the legal consolidation of the ecological function of the state. In this way, preserving the environment for present and future generations in modern law theory and constitutional practice is seen as a shared responsibility of the state, civil society and man. This approach can be defined as an international legal environmental imperative, which is accepted in almost every country in the world.

The creation of a new environmental ethic in the global civil society of the post-industrial era. The ethics of global civil society will be guided by the priority of human interests, the desire to preserve and pass on the Earth and modern civilization to the next generations [5].

Further development of the Institute for Environmental Rights and Freedoms should take into account the emerging trends of mutual "transfusion" of scientific ideas and provisions between national legislation and international environmental law, especially the processes of globalization. It has become generally accepted the constitutional consolidation of environmental responsibilities of citizens, which corresponds to the environmental right to a life-friendly and clean environment.

\section{References:}

1. Алексеев С.С. Абэтка. Теория. Философия. Опыт комплексных исследований. Москва : Хартия, 1999.

2. Костицький В.В. Екологія перехідного періоду: право, держава, економіка (економіко-правовий механізм охорони навколишнього середовища в Україні) / Інститут законодавчих прогнозів та правової експертизи. Київ : USSB SME Eusmeu, 2003. $772 \mathrm{c}$.

3. Екологічна конституція Землі. Методологічна основа / В.В. Костицький та ін. Львів : РВВ НЛТУ України, 2011. C. $370-381$.

4. Протасов В.Ф., Молчанов А.В. Словарь экологических терминов и понятий. Москва, 1997. С. 101.

5. Проблеми теорії екологічного права : колективна монографія / В.В. Костицький, А.П. Гетьман, Ю.В. Щокін, Ю.А. Гетьман та ін. ; за ред. В. Костицького. Львів - Торунь : Liha-Pres, 2020. 112 с. 